\title{
MODELLING OF THE AXISYMMETRIC PRECISION ELECTROCHEMICAL SHAPING
}

\author{
V.P. Zhitnikov ${ }^{1}$, N.M. Sherykhalina ${ }^{1}$, S.S. Porechny ${ }^{1}$, A.A. Sokolova ${ }^{1}$ \\ Ufa State Aviation Technical University, Ufa, Russian Federation \\ E-mails: zhitnik@mail.ru,n_sher@mail.ru, porechny@mail.ru, \\ alexandrakrasich@gmail.com
}

\begin{abstract}
The problem on modelling of a precision shaping and boundary conditions are formulated according to Faraday's law and with applying of stepwise dependence current efficiency on current density. The problem is reduced to the solution of a boundary problem for definition of two analytical functions of the complex variable. The first function is a conformal mapping of region of parametrical variable on the physical plane. In order to determine this function we use the Schwartz's integral and a spline interpolation. Unlike a plane problem for determination of potential and stream function of an axisymmetric field, the integration transformations of the second analytical function are used. The analytical function is defined in the form of a sum of two addends. The first addend takes into account the singularities of the function so that the second addend has no singularities. The second function is defined by the Schwartz's integral. Interpolation by spline functions is carried out, where the spline coefficients are derivatives of these functions by means of which the intensity vector components are calculated. We propose the method to solve the axisymmetric stationary problems, which differs from the known methods by the accuracy. By means of the method, we obtain the numerical results, describing the workpiece form. The error estimation of the obtained results is carried out. Also, we show qualitative coincidence with results of plane problem solution.
\end{abstract}

Keywords: electrochemical shaping; stepwise function; precision model; error estimation.

\section{Introduction}

Electrochemical dimensional machining is one of the promising ways to obtain complex-shaped parts from hard-to-machine materials. In addition, during electrochemical machining (ECM) the electrode - tool (ET) practically does not influence to the detail mechanically and thermally. But, the determination of the machined surface shape is a complicated problem [1].

Simulation of ECM is based on the Faraday's law, according to which the dissolution rate $V_{\text {ecm }}$ is as follows [1]:

$$
V_{e c m}=\frac{k}{\kappa} \eta j, \quad k=\frac{\kappa \varepsilon}{\rho},
$$

where $\varepsilon$ is the electrochemical equivalent; $\rho$ is the density of the dissolved material; $\kappa$ is the electrolyte conductivity; $j$ is the current density on the anode boundary; $\eta=\eta(j)$ is the current efficiency (the fraction of the current taking part in the metal dissolution reaction).

In this paper, the dependence of the current efficiency on the current density is modeled by the stepwise function [1]: 


$$
\eta(j)= \begin{cases}\eta_{0}, & j>j_{1} \\ 0 \leq \eta \leq \eta_{0}, & j=j_{1} \\ 0, & j<j_{1} .\end{cases}
$$

We consider a machining mode called the limit stationary one, at which at each point of the anode, where dissolution occurs, $j=j_{1}$, and $\eta$ may change from $\eta_{0}$ to zero or some minimum value. In this case, the highest degree of localization of the dissolution process is achieved [1]. Heating of the electrolyte and gas filling is neglected, i.e. the ideal process in a homogeneous electrolyte is under consideration. Assuming that the environment is ideal we can apply the methods of the theory of functions of a complex variable to solve the problem. Two-dimensional plane models of ECM [2-11] have become widespread. Three dimensional problems of general form were also previously considered [12-14]. This work is devoted to axisymmetric models with variable current efficiency. Such problems are not previously solved, although they are of great interest.

\section{Problem Statement}

Consider the problem of the Laplace equation solving for the electric field potential $\Phi$ inside some axially symmetric area. The condition of constancy of $\Phi$ hollos on the area boundary. The conditions on the machined surface (anode) areas are discussed below.

We consider the stationary problem of point electrode-tool (ET) machining. The meridional cross section of the inter-electrode space (IES) is shown in Fig. 1. Here $A D A^{\prime \prime}$ is the boundary of the dissolved material, the point $C$ is the point ET moving with the velocity $V_{e t}$ to the machined surface.

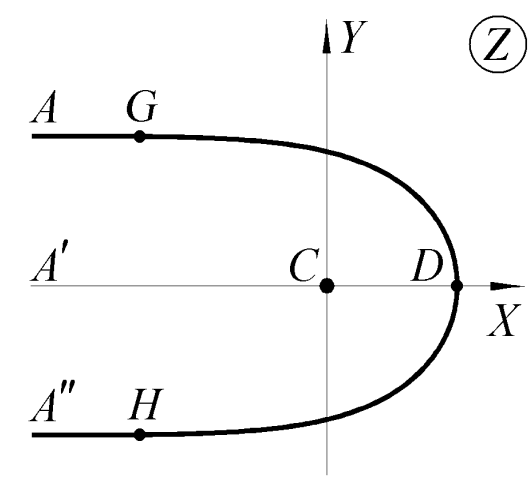

Fig. 1. Scheme of IES for limit stationary process: $G D H$ is the zone of the constant (threshold) value of strength; $A G$ and $A^{\prime \prime} H$ are the undissolved (rectilinear) boundaries.

The potential $\Phi$ and the stream function $\Psi$ of an axisymmetric field are expressed by the function $f(z)$ of the complex variable $Z$. The function $f(z)$ analytic (i.e., $f(z)$ satisfies the Cauchy-Riemann equations $[15,16])$ in the area $Z=X+i Y$. Apply the formulas of the Polozhy integral transformations [17]:

$$
\Phi\left(X_{0}, Y_{0}\right)=-\frac{1}{\pi} \operatorname{Im} \int_{X_{1}}^{Z_{0}} f(Z) \frac{d Z}{\sqrt{\left(Z-Z_{0}\right)\left(Z-\bar{Z}_{0}\right)}},
$$




$$
\Psi\left(X_{0}, Y_{0}\right)=\frac{1}{\pi} \operatorname{Im} \int_{X_{1}}^{Z_{0}} f(Z) \frac{\left(Z-X_{0}\right) d Z}{\sqrt{\left(Z-Z_{0}\right)\left(Z-\bar{Z}_{0}\right)}},
$$

where $Z_{0}=X_{0}+i Y_{0}$ and $\bar{Z}_{0}=X_{0}-i Y_{0} . X_{1}+i 0$ is some point on the axis of symmetry $X$.

Thus, the potential and stream function of the axisymmetric problem are determined using plane complex variable function $f(Z)=d W / d Z$ [18].

The boundary conditions of the auxiliary plane problem are written in the form of integral equations, which are obtained by equating to the constant the right-hand side both in (3) for equipotential boundaries and in (4) for isolated ones in the general case. The equality to zero of the imaginary or real part of $f(Z)$ does not lead to equality to zero or a constant of the corresponding integrals.

We map conformally the area corresponding to the IES on the plane $Z$ onto the band $\chi=\sigma+i v$ (Fig. 2, a). Therefore, the problem on determining the function $W(Z)$, which is analytic in the field of the IES, can be solved in a parametric form and we find $W(\chi)$ and $Z(\chi)$.

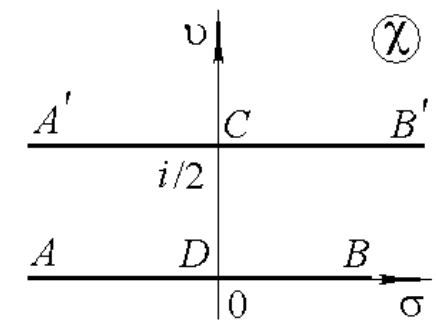

a

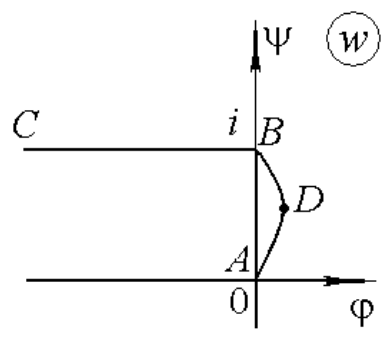

b

Fig. 2. The images of the IES on the planes for the parametric variable $\chi$ : (a) and for the plane complex potential $w(z)(\mathrm{b})$

\section{Boundary Conditions}

The boundary condition for the function $W(\chi)$ determination is the condition of axisymmetric anode equipotentiality $\Phi_{a}=0$ (3). In this case, on the plane $w=W / U$, the image of the IES region is a curvilinear half-band (Fig. 2, b). In the calculations, it is more convenient to use dimensionless values

$$
z=\frac{Z}{l}, \quad x=\frac{X}{l}, \quad y=\frac{Y}{l}, \quad \varphi=\frac{\Phi \kappa l}{I}, \quad \psi=\frac{\Psi \kappa}{I}, \quad \tau=\frac{V_{e t} t}{l},
$$

where $l$ is the character size; $I$ is the current; $t$ is the time. The dimensionless velocity of $\mathrm{ET}$ is $v_{e t}=d x_{C} / d \tau=1$.

According to the Faraday's law for $\eta=\eta_{0}=$ const, the amount of dissolved metal is

$$
\frac{k \eta_{0}}{\kappa} \Delta Q=\frac{k \eta_{0}}{\kappa} I \Delta t=V_{e t} S \Delta t
$$

where $Q$ is the charge flowing in the chain during the time $\Delta t, S$ is the cross-sectional area of the groove formed during the penetration of ET into the workpiece body $S=\pi R^{2} ; R$ 
is the radius of the groove. Then we obtain the formula

$$
\pi R^{2}=\frac{k \eta_{0} I}{\kappa V_{e t}}, \quad l=2 R=\frac{2}{\sqrt{\pi}} \sqrt{\frac{k \eta_{0} I}{\kappa V_{e t}}} .
$$

The dimensionless strength of the electric field at the equipotential anode is

$$
e_{x}+i e_{y}=\frac{\partial \varphi}{\partial x}+i \frac{\partial \varphi}{\partial y}=\frac{1}{y} \frac{\partial \psi}{\partial y}-i \frac{1}{y} \frac{\partial \psi}{\partial x}=-\frac{i}{y} \frac{\partial \psi}{\partial \sigma} \overline{\left(\frac{\partial z}{\partial \sigma}\right)}^{-1} .
$$

In this case, from the condition of equality of the ET velocity $V_{e t}$ and the rate $V_{D}$ of dissolution at the point $D$ in the stationary process, using (1), we obtain $V_{e t}=k \eta_{0} E_{D}$, $e_{D}=l E_{D} / U=4 / \pi$. The boundary condition for determining the function $Z(\chi)$ in the limiting case is the condition

$$
\left|e_{x}+i e_{y}\right|=\frac{1}{y} \frac{\partial \psi}{\partial \sigma}\left|\frac{\partial z}{\partial \sigma}\right|^{-1}=\frac{4}{\pi}
$$

which holds on the boundary section $\chi=\sigma+i 0,0 \leq \sigma \leq \sigma_{1}$, where the dissolution occurs.

On the section $\sigma>\sigma_{1}$, where dissolution does not occur, the value $y(\sigma)=y\left(\sigma_{1}\right)$ remains.

\section{Conformal Mapping}

We use the parametric variable $\chi$ as a band of width $1 / 2$ (Fig. 2(a)).

As a first step of the solution method, the function that maps the plane $\chi$ to the physical one is searched in the form of the sum

$$
z(\chi)=g z_{0}(\chi)+z_{\Delta}(\chi)
$$

For $\chi \rightarrow \infty$, the magnitude $\operatorname{Im} z_{\Delta}(\chi) \rightarrow 0$. The function

$$
z_{0}=-\frac{2}{\pi} \ln \operatorname{ch} \frac{\pi}{2}\left(\chi-\frac{i}{2}\right)=-\frac{1}{\pi} \ln \frac{\operatorname{ch} \pi \sigma}{2}+\frac{i}{\pi} \operatorname{arctg} \operatorname{sh} \pi \sigma
$$

is the solution of the plane stationary problem [19] with constant current efficiency. The boundary $\chi=\sigma+i 0$ maps onto the surface $A D B$, and the boundary $\chi=\sigma+i / 2$ maps onto the cut $A^{\prime} C^{\prime} B$. The location of the point source is $z_{0}(i / 2)=0$. The derivatives are as follows:

$$
\frac{d z_{0}}{d \chi}=-\operatorname{th} \frac{\pi}{2}\left(\chi-\frac{i}{2}\right)=\frac{i}{2} \frac{\operatorname{ch} \pi \chi}{\operatorname{ch}^{2} \frac{\pi}{2}\left(\chi-\frac{i}{2}\right)}, \quad \frac{d z_{0}}{d \sigma}=\left(-\operatorname{th} \pi \sigma+\frac{i}{\operatorname{ch} \pi \sigma}\right) .
$$

The value of the coefficient $g$ in (7) is determined from the condition

$$
\operatorname{Im} z_{\Delta}(\infty+i 0)=0 .
$$

Then we have the equations

$$
y\left(\sigma_{1}\right)=y_{\Delta}\left(\sigma_{1}\right)+g \frac{1}{\pi} \operatorname{arctg} \operatorname{sh} \pi \sigma_{1},
$$




$$
y(\infty)=0+g \frac{1}{\pi} \frac{\pi}{2}=y\left(\sigma_{1}\right) .
$$

We solve the equations above and find

$$
\begin{gathered}
y(\infty)=0+g \frac{1}{\pi} \frac{\pi}{2}=y\left(\sigma_{1}\right) . \\
g=2 y\left(\sigma_{1}\right)=\frac{2 y_{\Delta}\left(\sigma_{1}\right)}{1-\frac{2}{\pi} \operatorname{arctg} \operatorname{sh} \pi \sigma_{1}}, \quad y_{\Delta}(\sigma)=y\left(\sigma_{1}\right)-g \frac{1}{\pi} \operatorname{arctg} \operatorname{sh} \pi \sigma .
\end{gathered}
$$

The function $z_{\Delta}(\chi)$ is obtained as follows. We find the solution on the boundary $\chi=\sigma$, $0 \leq \sigma \leq \sigma_{1}$ at the node points $\sigma_{m}(m=0, \ldots, n)$. The values $\operatorname{Im} z_{\Delta}\left(\sigma_{m}\right)=y_{m}$ are to be found. We use a cubic spline $P(\sigma)$ to obtain the values $\operatorname{Im} z_{\Delta}(\sigma)$ at the points between node ones.

Note, that an analytic function $z_{\Delta}(\chi)$ has the purely real values for $\operatorname{Im} \chi=1 / 2$. Then we analytically continue this function to a band $0<\chi<1$. Then $\operatorname{Im} z_{\Delta}(\sigma+i)=$ $\left.-\operatorname{Im} z_{\Delta}(\sigma+i 0)\right)$. Because of $z_{\Delta}(\sigma+i 0)$ is an odd function we use the Schwarz formula in the form [15] to restore the $z_{\Delta}(\chi)$

$$
z_{\Delta}(\chi)=\int_{0}^{\infty} P(\sigma) \frac{\operatorname{sh} \pi \sigma}{\operatorname{ch} \pi \sigma+\operatorname{ch} \pi \chi} d \sigma+\int_{0}^{\infty} P(\sigma) \frac{\operatorname{sh} \pi \sigma}{\operatorname{ch} \pi \sigma-\operatorname{ch} \pi \chi} d \sigma .
$$

The derivative $\frac{\partial z_{\Delta}}{\partial \sigma}(\sigma)$ is determined as follows. The coefficients of the spline $P(\sigma)$ are equal to the derivatives $\frac{\partial y_{\Delta}}{\partial \sigma}\left(\sigma_{m}\right)$. The values $x_{\Delta}\left(\sigma_{m}\right)$ obtained from (10) are interpolated by the spline $P_{1}(\sigma)$. The coefficients of the spline are equal to the values $\frac{\partial x_{\Delta}}{\partial \sigma}\left(\sigma_{m}\right)$.

Note that $z_{0}(i / 2)=0$ according to $(8),(10)$, and

$$
z_{\Delta}(i / 2)=2 \int_{0}^{\infty} P(\sigma) \operatorname{th} \pi \sigma d \sigma
$$

\section{The Potential and Stream Function Determination}

Axisymmetric problem is solved by reducing to the auxiliary plane problem. In order to solve the problem, the area corresponding to the IES on the plane of the complex potential (Fig. 2, b) is conformally mapped onto the plane of the parametric variable $\chi$ (Fig. 2, a). The method of problem solving consists of representation of the potential and stream functions as the sums

$$
\begin{gathered}
\varphi\left(x_{0}, y_{0}\right)=\varphi_{0}\left(x_{0}, y_{0}\right)+\varphi_{1}\left(x_{0}, y_{0}\right)= \\
=-\frac{1}{4 \pi} \frac{1}{\sqrt{\left(x_{0}+1\right)^{2}+y_{0}^{2}}}-\frac{1}{\pi} \operatorname{Im} \int_{0}^{\sigma_{0}} \frac{\partial w_{1}}{\partial \sigma}(\sigma) \frac{d \sigma}{\sqrt{\left(z(\sigma)-z_{0}\right)\left(z(\sigma)-\bar{z}_{0}\right)}}, \\
\psi\left(x_{0}, x_{0}\right)=\psi_{0}\left(x_{0}, x_{0}\right)+\psi_{1}\left(x_{0}, x_{0}\right)= \\
=-\frac{1}{4 \pi} \frac{x_{0}+1}{\sqrt{\left(x_{0}+1\right)^{2}+y_{0}^{2}}}+\frac{1}{\pi} \operatorname{Im} \int_{0}^{\sigma 0} \frac{\partial w_{1}}{\partial \sigma}(\sigma) \frac{\left(z(\sigma)-x_{0}\right) d \sigma}{\sqrt{\left(z(\sigma)-z_{0}\right)\left(z(\sigma)-\bar{z}_{0}\right)}}
\end{gathered}
$$

where the first terms represent the potential and stream function of the point source [19]. 
We find the solution in the form of the function

$$
f_{1}(\chi)=\frac{\partial w_{1}}{\partial \chi}(\chi)
$$

The desired parameters are the values of the real part of the function $\operatorname{Re} f_{1}\left(\sigma_{m}\right)=f_{m}$ at the node points $\sigma_{m},(m=1, \ldots, 2 n)$. For $\sigma=\sigma_{0}=0$, we have $\operatorname{Re} f_{1}\left(\sigma_{0}\right)=0$, since the real part of $f_{1}$ is an odd function of $\sigma$. For $\sigma=\sigma_{2 n}$, we accept $\operatorname{Re} f_{1}\left(\sigma_{2 n}\right)=0$. The values of $\operatorname{Re}_{1}(\sigma)$ at intermediate between the node points are found using the cubic spline $S(\sigma)$. In order to restore the function $f_{1}(\chi)$, we use the Schwartz formula [15].

This function must have the following properties: the real part must be an odd function of $\sigma$ for $\chi=\sigma+i 0$ and must be purely real; for $\chi=\sigma+i / 2$. Then the function can be analytically continued to a band of unit width. Thus, $\operatorname{Re} f_{1}(\sigma+i)=\operatorname{Re} f_{1}(\sigma+i 0)$. Therefore, similarly to (10),

$$
f_{1}(\chi)=i\left[\int_{0}^{\infty} S(\sigma) \frac{\operatorname{sh} \pi \sigma}{\operatorname{ch} \pi+\operatorname{ch} \pi \chi} d \sigma-\int_{0}^{\infty} S(\sigma) \frac{\operatorname{sh} \pi \sigma}{\operatorname{ch} \pi \sigma-\operatorname{ch} \pi \chi} d \sigma\right] .
$$

Substituting the expression of $f_{1}(\sigma)$ through a spline and Schwartz's formula in (11), (12) use Sokhotsky's formula [15], we obtain

$$
\begin{aligned}
& \varphi_{1}\left(\sigma_{m}\right)=-\frac{1}{\pi} \operatorname{Im} \int_{0}^{\sigma_{m}}\left(S(\sigma)-2 i v \cdot p \cdot \int_{0}^{\infty} S(p) \frac{\operatorname{ch} \pi \sigma \operatorname{sh} \pi p d p}{\operatorname{ch}^{2} \pi p-\operatorname{ch}^{2} \pi \sigma}\right) \frac{d \sigma}{\sqrt{\left(z-z\left(\sigma_{m}\right)\right)\left(z-\bar{z}\left(\sigma_{m}\right)\right)}}, \\
& \psi_{1}\left(\sigma_{m}\right)=\frac{1}{\pi} \operatorname{Im} \int_{0}^{\sigma_{m}}\left(S(\sigma)-2 i v \cdot p \cdot \int_{0}^{\infty} S(p) \frac{\operatorname{ch} \pi \sigma \operatorname{sh} \pi p d p}{\operatorname{ch}^{2} \pi p-\operatorname{ch}^{2} \pi \sigma}\right) \frac{\left(z-x\left(\sigma_{m}\right)\right) d \sigma}{\sqrt{\left(z-z\left(\sigma_{m}\right)\right)\left(z-\bar{z}\left(\sigma_{m}\right)\right)}} .
\end{aligned}
$$

The condition of equipotentiality of the machined surface $\chi=\sigma$ for solving by the collocation method leads to the system of equations

$$
F_{m}=\varphi\left(\sigma_{m}\right)-\varphi\left(\sigma_{2 n}\right)=0, \quad m=1, \ldots, 2 n-1 .
$$

Condition (6) represents a nonlinear equation for the unknown function $z_{\Delta}(\sigma)$. The problem is solved by the method of collocations. The sought values are $\operatorname{Im} z_{\Delta}\left(\sigma_{m}\right)=y_{m}$, $(m=1, \ldots, n-1), \operatorname{Re}_{1}\left(\sigma_{m}\right)=f_{m}(m=1, \ldots, 2 n-1)$ at the node points $\sigma_{m}$ (as mentioned above, $\left.y_{0}=0, f_{0}=f_{2 n}=0\right)$. In order to determine these parameters we construct a system of nonlinear equations. We require that equation (6) holds for $\sigma=\sigma_{m}(m=1, \ldots, n-1)$ and equation (13) holds for $\sigma=\sigma_{m}(m=1, \ldots, 2 n-1)$. The image of the point $G$ on the plane $\chi\left(\sigma_{n}\right)$ is also the required parameter. The equation $\frac{d S}{d \sigma}\left(\sigma_{n}\right)=0$ is included in the system to determine this parameter. The maximum value of $\sigma_{2 n}$ is chosen to be equal to 12. Therefore, we obtain the system of $3 n-1$ nonlinear equations, which is solved by the Newton method with step regulation.

\section{Numerical Results}

Figs. 3, 4 show the shapes of the machined surface, as well as the dependence of strength on the abscissa of the machined surface, in comparison with the plane case, the 
solution of which is obtained by the formula

$$
Z=\frac{i}{3 \sqrt{3} \pi E_{1}}\left[\frac{-6}{\sqrt{3 \sin ^{-2} \pi \psi-4}+2 i}+i \ln \frac{\sqrt{3 \sin ^{-2} \pi \psi-4}+2 i}{\sqrt{3 \sin ^{-2} \pi \psi-4}-i}-i \frac{3}{2}-2 i \ln 2\right] .
$$

According to this formula, for the plane problem we have

$$
x_{D}=\frac{1}{3 \sqrt{3} \pi}\left(\frac{3}{2}+2 \ln 2\right), \quad y_{G}=\frac{1}{3 \sqrt{3} \pi} .
$$

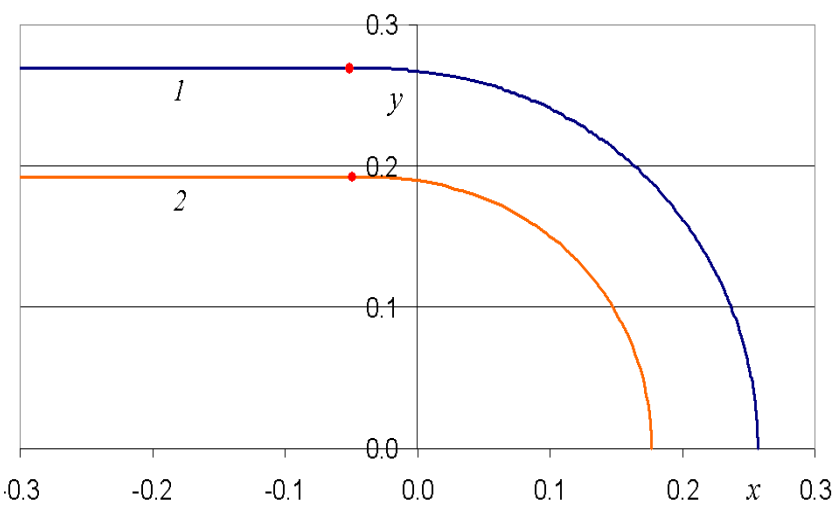

Fig. 3. Comparison of limit stationary shapes for the axisymmetric problem (the 1-st curve) and for the plane problem (the 2-nd curve)

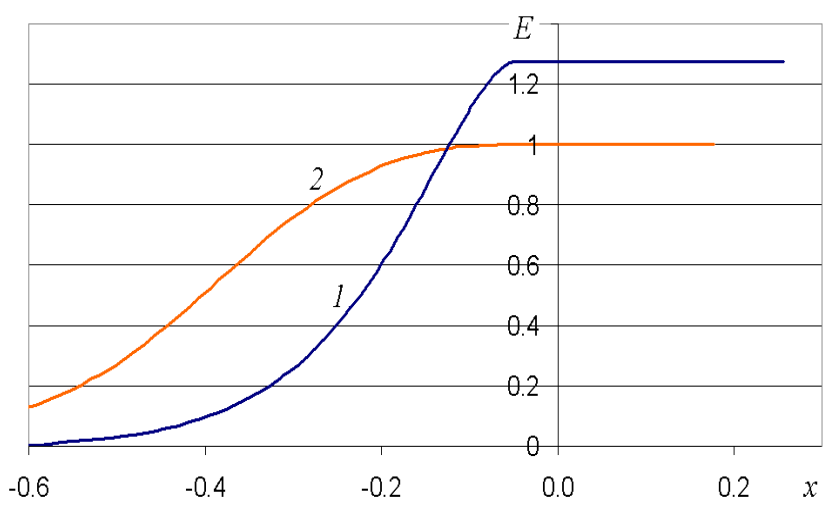

Fig. 4. Dependence of the dimensionless strength on the abscissa for the axisymmetric problem (the 1-st curve) and for the plane problem (the 2-nd curve)

Nonstationary machining process is shown at unmoving coordinate system in Fig. 5 (a) and at coordinate system connected with ET in Fig. 5 (b). The rapid formation of limit stationary configuration is observed. We compute the nonstationary process by the modified method described in $[1,18,19]$. The comparison of the obtained solution with the solution to the limit stationary problem shows their coincidence up to estimated error.

The estimation of the numerical solution error is carried out by the method of calculation results filtration [20]. Fig. 6 presents the filtration results on a logarithmic scale. The ordinate axis is the decimal logarithm of the absolute values of the obtained estimates of the relative errors $\delta$, therefore $-\lg \delta$ is the obtained data accuracy. The 


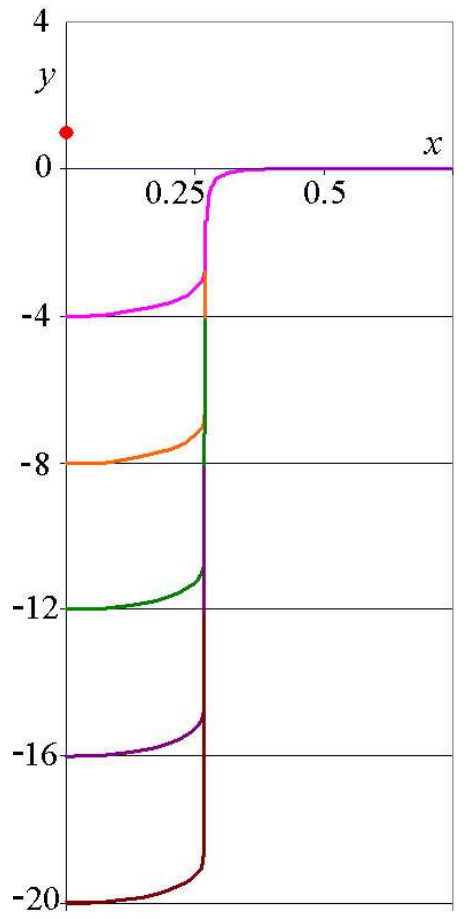

a)

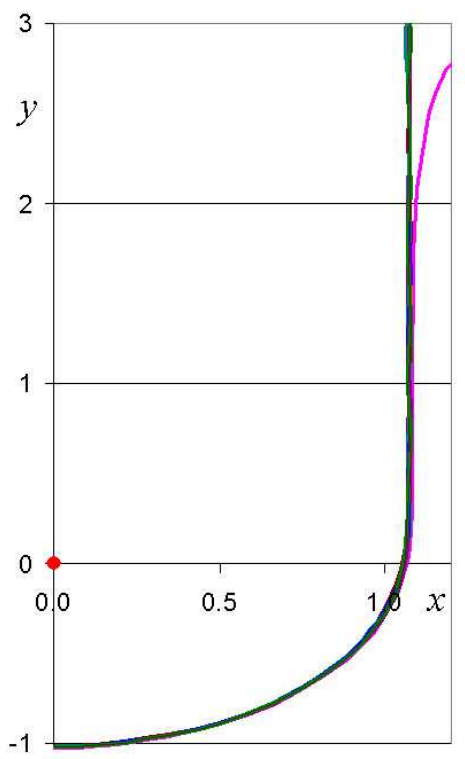

b)

Fig. 5. Nonstationary forms of the machining surface for $\Delta \tau=4$ in the unmoving coordinate system (a) and in the coordinate system connected with ET (b)

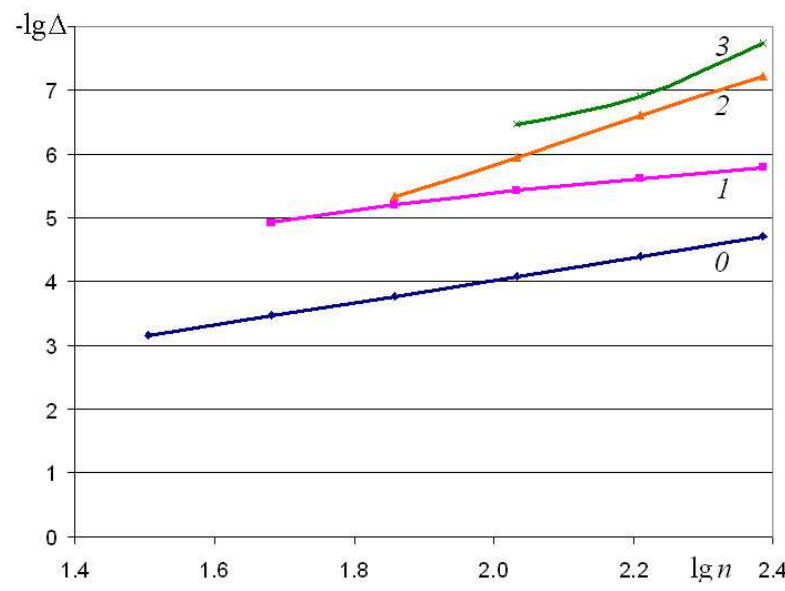

a)

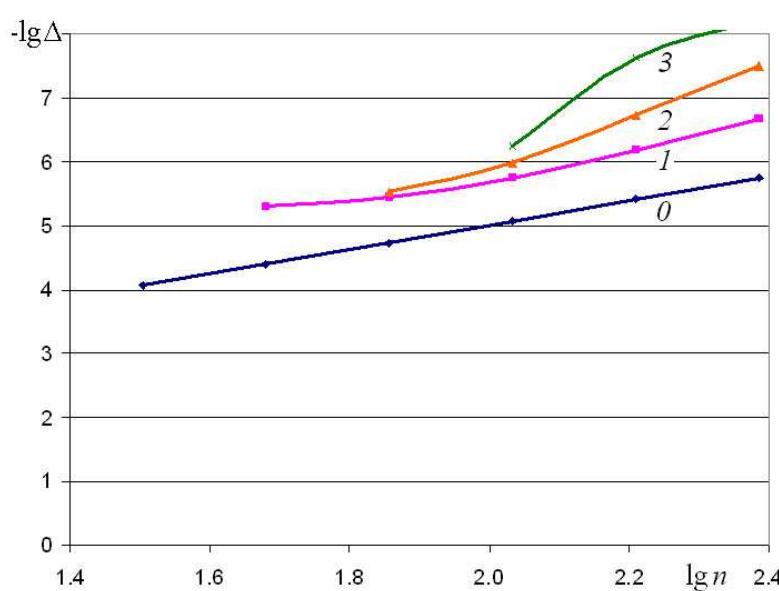

b)

Fig. 6. Estimate of the relative error of the axisymmetric problem solution for the abscissas of the center point $D(\mathrm{a})$ and for the ordinates of the point $G$ (b)

decimal logarithms of the number of segments $n$ (which varies from 32 to 243 with the increase of 1,5 times) are plotted on the abscissa axis. The abscissa of the center point $x_{D}$ in Fig. 6 (a) and the ordinate of the transition point $y_{G}$ in Fig. 6 (b) are considered as the estimated parameters. The digit 0 marks the estimated accuracy of the computed data, the digits $1,2, \ldots$ are the results of the first, second, etc., filtration. The difference of the ordinates between the two curves is the logarithm of the ratio of the estimates for different filtrations. This ratio is called an estimate blurriness. There is a violation of regularity due to round off error at the level of the $10^{-7}$. In Fig. 6 (a), the components of $n^{-1}, n^{-2}$ orders 
are found (the 2-nd order component turned out to be more powerful than the 1-st one). In Fig. 6 (b), the component orders start from the 2 -nd one. The values $x_{D}=0,2678119 \pm 10^{-7}$ and $y_{G}=0,283235439 \pm 10^{-7}$ are obtained using filtration.

\section{Conclusion}

Thus, in this paper it is offered the method for the numerical solution of the problem of limit stationary electrochemical machining by a point electrode-tool. This method and algorithm realizing it use the integral transformations of an analytical function. The numerical values (with its error estimate) of geometric parameters are obtained. For example, the boundary coordinates values are calculated with the high accuracy about 7 significant digits.

Acknowledgments. This work was financially supported by the Russian Foundation for Basic Research (Project code 17-07-00356).

\section{References}

1. Zhitnikov V.P., Sherykhalina N.M., Porechny S.S. Comparison of Quasi-Stationary and Non-Stationary Solutions of Electrochemical Machining Problems Applying to Precision Cutting with Plate Electrode-Tool. Bulletin of the South Ural State University. Series: Mathematical Modelling, Programming and Computer Software, 2019, vol. 12, no. 1, pp. 5-19. DOI: $10.14529 / \mathrm{mmp} 190101$

2. Christiansen S., Rasmussen H. Numerical Solutions for Two-Dimensional Annular Electrochemical Machining Problems. Journal of the Institute of Mathematics and Its Applications, 1976, no. 18, pp. 295-307. DOI: 10.1093/imamat/18.3.295

3. Klokov V.V. Influence of Alternating Current Output on Stationary Anode Shaping. Workshop of the Seminar on Boundary Value Problems, 1979, vol. 16, pp. 94-102. (in Russian)

4. Gazizov E.R., Maklakov D.V. A Method for Calculating Anodic Shaping by a Dihedral Cathode for an Arbitrary Current-Output Dependence. Teorija $i$ praktika elektrofizikokhimicheskikh metodov obrabotki detaley $v$ aviastrojenii [Theory and Practice of Electrophysico-Chemical Methods of Processing Details in Aircraft Building], 1994, pp. 32-35. (in Russian)

5. Datta M., Landolt D. Fundamental Aspects and Applications of Electrochemical Microfabrication. Electrochimica Acta, 2000, vol. 45, pp. 2535-2558. DOI: 10.1016/S0013-4686(00)00350-9

6. Hong Shik Shin, Bo Hyun Kim, Chong Nam Chu. Analysis of the Side Gap Resulting from Micro Electrochemical Machining with a Tungsten Wire and Ultrashort Voltage Pulses. Journal of Micromechanics and Microengineering, 2008, vol. 18, pp. 1-6. DOI: 10.1088/09601317/18/7/075009.

7. Shaohua Wang, Di Zhu, Yongbin Zeng, Yong Liu. Micro Wire Electrode Electrochemical Cutting with Low Frequency and Small Amplitude Tool Vibration. International Journal of Advanced Manufacturing Technology, 2011, vol. 53, no. 5-8, pp. 535-544. DOI: $10.1007 / \mathrm{s} 00170-010-2835-8$

8. Ningsong Qu, Xiaolong Fang, Weidong Li, Yongbin Zeng, Di Zhu. Wire Electrochemical Machining with Axial Electrolyte Flushing for Titanium Alloy. Chinese Journal of Aeronautics, 2013, vol. 26, no. 1, pp. 224-229. DOI: 10.1016/j.cja.2012.12.026 
9. Kotlyar L.M., Minazetdinov N.M. Modeling of Electrochemical Machining with the Use of a Curvilinear Electrode and a Stepwise Dependence of the Current Efficiency on the Current Density. Journal of Applied Mechanics and Technical Physics, 2016, vol. 57(1), pp. 127-135. DOI: $10.1134 /$ S0021894416010144

10. Volgin V.M., Lyubimov V.V., Gnidina I.V., Davydov A.D., Kabanova T.B. Effect of Current Efficiency on Electrochemical Micromachining by Moving Electrode. Procedia CIRP, 2016, vol. 55, pp. 65-70. DOI: 10.1016/j.procir.2016.08.031

11. Yuanlong Chen, Ming Fang, Lijun Jiang. Multiphysics Simulation of the Material Removal Process in Pulse Electrochemical Machining. International Journal of Advanced Manufacturing Technology, 2017, vol. 91, pp. 2455-2465. DOI: 10.1007/s00170-016-9899-z

12. Purcar M., Bortels L., Van den Bossche B., Deconinck J. 3D Electrochemical Machining Computer Simulations. Journal of Materials Processing Technology, 2004, vol. 149, no. 1-3, pp. 472-478. DOI: 10.1016/j.jmatprotec.2003.10.050

13. Zhouzhi Gu, Weiguo Zhu, Xiaohu Zheng, Xiaomin Bai. Cathode Design Investigation Based on Iterative Correction of Predicted Profile Errors in Electrochemical Machining of Compressor Blades. Chinese Journal of Aeronautics, 2016, vol. 29, no. 4, pp. 1111-1118. DOI: $10.1016 /$ j.cja.2016.01.003

14. Cheng Guo, Jun Qian, Reynaerts D. Electrochemical Machining with Scanning Micro Electrochemical Flow Cell. Journal of Materials Processing Technology, 2017, vol. 24, no. 7, pp. 171-183. DOI: 10.1016/j.jmatprotec.2017.04.017

15. Lavrentiev M.A., Shabat B.V. Metody teorii funktsiy kompleksnogo peremennogo [Methods of the Theory of Functions of a Complex Variable]. Moscow, Nauka, 1987. (in Russian)

16. Henrici P. Computational Complex Analysis. N.Y., Wiley Classic Library, 1993.

17. Polozhiy G.N. Obobshchenie teorii analiticheskih funkcij kompleksnogo peremenogo [Generalization of Analytic Functions of Complex Variable Theory]. Kiev, Kiev University, 1965.

18. Zhitnikov V.P., Zinnatullina O.R., Porechny S.S., Sherykhalina N.M. Determining the Limiting Solutions of Nonstationary Axisymmetric Hele-Shaw Problems. Journal of Applied Mechanics and Technical Physics, 2009, vol. 50, no. 4, pp. 617-627. DOI: $10.1007 / \mathrm{s} 10808-009-0083-1$

19. Zhitnikov V.P., Sherykhalina N.M., Zaripov A.A. Modelling of Precision Steady-State and Non-Steady-State Electrochemical Machining by Wire Electrode-Tool. Journal of Materials Processing Technology, 2016, vol. 235, pp. 49-54. DOI: 10.1016/j.jmatprotec.2016.03

20. Zhitnikov V.P., Sherykhalina N.M., Sokolova A.A. Problem of Reliability Justification of Computation Error Estimates. Mediterranean Journal of Social Sciences, 2015, vol. 6, no. 2, pp. 65-78. DOI: 10.5901/mjss.2015.v6n2s4p65

Received April 24, 2019 
УДК 621.9.047

DOI: $10.14529 / \mathrm{mmp200103}$

\title{
МОДЕЛИРОВАНИЕ ОСЕСИММЕТРИЧНОГО ПРЕЦИЗИОННОГО ЭЛЕКТРОХИМИЧЕСКОГО ФОРМООБРАЗОВАНИЯ
}

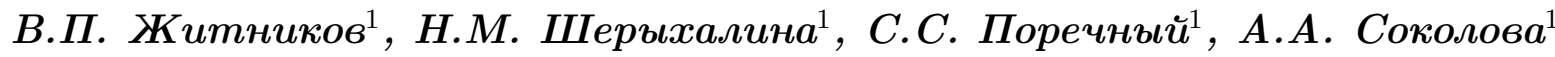 \\ Уфимский государственный авиационный технический университет, г. Уфа, \\ Российская Федерация
}

Проблема моделирования прецизионного формообразования и граничные условия сформулированы согласно закону Фарадея со ступенчатой зависимостью выхода по току от плотности тока. Задача сводится к решению краевой задачи для определения двух аналитических функций комплексного переменного. Первая функция производит конформное отображение области параметрического переменного на физическую плоскость. Для этого используется интеграл Шварца и интерполяция сплайном. В отличие от плоской задачи, для определения потенциала и функции тока осесимметричной задачи используются интегральные преобразования второй аналитической функции. Аналитическая функция определена в форме суммы двух слагаемых. Первое слагаемое учитывает особенности функции так, чтобы у второго слагаемого не было особенностей. Вторая функция определяется с помощью интеграла Шварца. Проводится интерполяция функций сплайнами третьей степени, при этом коэффициенты сплайнов равны производным этих функций, посредством которых вычисляются компоненты векторов напряженности. Предложен метод решения осесимметричных стационарных задач, который отличается от известных методов своей точностью. С помощью предложенного метода получены численные результаты, описывающие форму обрабатываемой поверхности. Выполнена оценка погрешности полученных результатов. Проведено сравнение с результатами решения плоской задачи, которое показало их качественное совпадение.

Ключевые слова: электрохимическое формообразование; ступенчатая функиия; прецизионная модель; оченка погрешности.

\section{Литература}

1. Zhitnikov, V.P. Comparison of Quasi-Stationary and Non-Stationary Solutions of Electrochemical Machining Problems Applying to Precision Cutting with Plate ElectrodeTool / V.P. Zhitnikov, N.M. Sherykhalina, S.S. Porechny // Вестник ЮУрГУ. Серия: Математическое моделирование и программирование. - 2019. - Т. 12, № 1. - С. 5-19.

2. Christiansen, S. Numerical Solutions for Two-Dimensional Annular Electrochemical Machining Problems / S. Christiansen, H. Rasmussen // Journal of the Institute of Mathematics and Its Applications. - 1976. - № 18. - P. 295-307.

3. Клоков, В.В. Влияние переменного выхода по току на стационарное анодное формообразование / В.В. Клоков // Труды семинара по краевым задачам. Т. 16. - Казань: Казанский государственный университет, 1979. - С. 94-102.

4. Газизов, Е.Р. Метод расчета анодного формообразования двугранным катодом для произвольной зависимости выхода по току / Е.Р. Газизов, Д.В. Маклаков // Теория и практика электрофизикохимических методов обработки деталей в авиастроении. - Казань: Казанский авиационный институт, 1994. - С. 32-35.

5. Datta, M. Fundamental aspects and applications of electrochemical microfabrication / M. Datta, D. Landolt // Electrochimica Acta. - 2000. - V. 45. - P. 2535-2558.

6. Hong Shik Shin. Analysis of the Side Gap Resulting from Micro Electrochemical Machining with a Tungsten Wire and Ultrashort Voltage Pulses / Hong Shik Shin, Bo Hyun Kim, Chong Nam Chu // Journal of Micromechanics and Microengineering. - 2008. - V. 18. - P. 1-6. 
7. Shaohua Wang. Micro Wire Electrode Electrochemical Cutting with Low Frequency and Small Amplitude Tool Vibration / Shaohua Wang, Di Zhu, Yongbin Zeng, Yong Liu // International Journal of Advanced Manufacturing Technology. - 2011. - V. 53, № 5-8. - P. 535-544.

8. Ningsong Qu. Wire Electrochemical Machining with Axial Electrolyte Flushing for Titanium Alloy / Ningsong Qu, Xiaolong Fang, Weidong Li, Yongbin Zeng, Di Zhu // Chinese Journal of Aeronautics. - 2013. - V. 26, № 1. - P. 224-229.

9. Котляр, Л.М. Моделирование электрохимического формообразования с использованием криволинейного электрода при ступенчатой зависимости выхода по току от его плотности / Л.М. Котляр, Н.М. Миназетдинов // Прикладная механика и теоретическая физика. - 2016. - Т. 44, № 1. - С. 146-155.

10. Volgin, V.M. Effect of Current Efficiency on Electrochemical Micromachining by Moving Electrode / V.M. Volgin, V.V. Lyubimov, I.V. Gnidina, A.D. Davydov, T.B. Kabanova // Procedia CIRP. - 2016. - V. 55. - P. 65-70.

11. Yuanlong Chen. Multiphysics Simulation of the Material Removal Process in Pulse Electrochemical Machining (PECM) / Yuanlong Chen, Ming Fang, Lijun Jiang // International Journal of Advanced Manufacturing Technology. - 2017. - V. 91, № 5-8. - P. 2455-2465.

12. Purcar, M. 3D Electrochemical Machining Computer Simulations / M. Purcar, L. Bortels, B. van den Bossche, J. Deconinck // Journal of Materials Processing Technology. - 2004. V. 149, № 1-3. - P. 472-478.

13. Zhouzhi Gu. Cathode Design Investigation Based on Iterative Correction of Predicted Profile Errors in Electrochemical Machining of Compressor Blades / Zhouzhi Gu, Weiguo Zhu, Xiaohu Zheng, Xiaomin Bai // Chinese Journal of Aeronautics. - 2016. - V. 29, № 4. P. 1111-1118.

14. Cheng Guo. Electrochemical Machining with Scanning Micro Electrochemical Flow Cell / Cheng Guo, Jun Qian, D. Reynaerts // Journal of Materials processing Technology. 2017. - V. 24, № 7. - P. 171-183.

15. Лаврентьев, М.А. Методы теории функций комплексного переменного / М.А. Лаврентьев, Б.В. Шабат. - М.: Наука, 1987.

16. Henrici, P. Computational Complex Analysis / P. Henrici. - New-York: Wiley Classic Library, 1993.

17. Положий, Г.Н. Обобщение теории аналитических функций комплексного переменного / Г.Н. Положий. - Киев: Киевский университет, 1965.

18. Житников, В.П. Особенности установления предельных решений нестационарных осесимметричных задач Хеле - Шоу / В.П. Житников, О.Р. Зиннатуллина, С.С. Поречный, Н.М. Шерыхалина // Прикладная механика и теоретическая физика. - 2009. - Т. 50, № 4. - C. 87-99.

19. Zhitnikov, V.P. Modelling of Precision Steady-State and Non-Steady-State Electrochemical Machining by Wire Electrode-Tool / V.P. Zhitnikov, N.M. Sherykhalina, A.A. Zaripov // Journal of Materials Processing Technology. - 2016. - V. 235. - P. 49-54.

20. Zhitnikov, V.P. Problem of Reliability Justification of Computation Error Estimates / V.P. Zhitnikov, N.M. Sherykhalina, A.A. Sokolova // Mediterranean Journal of Social Sciences. - 2015. - V. 6, № 2. - P. 65-78. 
Владимир Павлович Житников, доктор физико-математических наук, професcop, кафедра «Вычислительная математика и кибернетика», Уфимский государственный авиационный технический университет (г. Уфа, Российская Федерация), zhitnik@mail.ru.

Наталия Михайловна Шерыхалина, доктор технических наук, доцент, кафедра «Вычислительная математика и кибернетика», Уфимский государственный авиационный технический университет (г. Уфа, Российская Федерация), n_sher@mail.ru.

Сергей Сергеевич Поречный, кандидат физико-математических наук, доцент, кафедра «Высокопроизводительные вычислительные технологии и системы», Уфимский государственный авиационный технический университет (г. Уфа, Российская Федерация), porechny@mail.ru.

Александра Алексеевна Соколова, кафедра «Вычислительная математика и кибернетика», Уфимский государственный авиационный технический университет (г. Уфа, Российская Федерация), n_alexandrakrasich@gmail.com.

Поступила в редакиию 24 апреля 2019 г. 